\section{Gregory Rift Valley and early man}

Geological Background to Fossil Man. Recent Research in the Gregory Rift Valley, East Africa. Edited by the late W. W. Bishop. (Scottish Academic Press: Edinburgh, 1978.) £25.

THE subtitle of this book is important, but it needs some explaining. The Gregory Rift Valley, for the benefit of non-geologists, is part of the great East African Rift-the system of valleys bounded by faults that extends southwards from the Red Sea for a distance of some $3,000 \mathrm{~km}$. The section of this system known as the Gregory Rift, if one is to be precise, runs only for about $450 \mathrm{~km}$ from the bottom end of Lake Turkana in northern Kenya to the Lake Natron and Ngorongoro areas in northern Tanzania. But for the purposes of this book, the Gregory Rift has been interpreted more widely to include the northwards extension of the Rift-otherwise called the Ethiopian Rift-to the Afar in northern Ethiopia. The important early man sites at Hadar, and those in the Omo Valley and east of Lake Turkana thus come within the book's scope.

By geological accident, the Gregory Rift Valley-in both narrow and wide senses-is a field laboratory perhaps without equal for palaeontological and archaeological studies of early man as well as for investigating the structural. volcanic and geophysical aspects of rift systems. It was therefore a good idea of the late W. W. (Bill) Bishop's to organise in February 1975 a meeting at the Geological Society of London of many of the geologists and others who had worked or were still working in different parts of this great valley. This book-a collection of 35 papers-is the outcome. Not all the contributions are geological, but all in one way or another add to knowledge of the development of the Gregory Rift Valley and the environment of early man at different times in this part of East Africa.

A major part of the book is about the geology and palaeontology of the Baringo Basin. This was the area in which Bishop, and also Basil C. King -Director of the East African Geological Research Unit and Bishop's Professor for a period-devoted much of their own and their students' time between the mid-1960s and mid-1970s. It is a loss to science that with Bishop's tragically early death in 1977 and King's retirement from the chair of geology at Bedford Colege, London, systematic geological and palaeontological surveying in the Baringo area has almost ceased, although an archaeological project at Chesowanja does continue.

As events have turned out, the book has become a memorial tribute to Bishop's geological work in East Africa. It is therefore a pity that the volume is not all that it might have been. Bishop unfortunately died before he had completed the introduction to the three main parts and also the summing-up, so the book lacks these sections-though this is not the publisher's fault. I was, however, sorry to see so many typographical errors and minor editorial inconsistencies for which the publisher should take responsibility. These are understandable in the circumstances, but are to be regretted nonetheless. I should also mention that 'recent' in the subtitle means no later than 1975-76.

Geological Background to Fossil Man remains, however, a useful record of research in the Gregory Rift Valley

\section{Ion-selective electrodes}

Analysis with Ion-Selective Electrodes. By J. Vesely, D. Weiss and K. Stulik. Pp.243. (Wiley: New York, London and Sydney, 1978.) $£ 16$.

ThE Ellis Horwood Series in Analytical Chemistry under the guidance of Dr R. A. Chalmers (Editor of Talanta) and Dr Mary Masson, of the University of Aberdeen, will be useful both to professional analysts, working in industry and the public services, and those few who teach analytical chemistry as a specialist subject in universities and polytechnics.

This volume is concerned with the applications of ion-selective electrodes as "sensors" that instrument technologists will need to interface with microprocessors-for example. when monitoring sodium and potassium levels for hospital patients. The authors are from Prague, home of $\mathbf{J}$. Heyrosky and polarography fame, which guarantees that their work rests on a good theoretical background. The translation is smooth and clear, so that English readers can easily follow their text.

The work is divided into four chapters; the last is long and devoted to analytical applications. The first two deal with introductory theory and instrumentation, in some seventy pages with more than 300 references. Exact treatments are given of the theory of membrane potentials and activities, classification of electrode types with details of their selectivities and response characteristics, and information about measuring instruments used in potentiometry. The third chapter gives and is especially valuable for the many geological maps and sections it contains. A special feature, and one that is rare these days, is the inclusion of a $1: 10,000$ coloured, foldout geological map of the area around Olorgesailie Prehistoric Site in Kenya. This map was prepared in 1946 by Robert M. Shackleton for the First Panafrican Congress of Prehistory in Nairobi but money was not available then for its publication. For this edition, grants towards the cost of publication have come from the Royal Society and the L. S. B. Leakey Foundation. The names of the stratigraphical units have been updated and the map was specially redrawn by Barbara Isaac. It accompanies a detailed account by Glynn L1. Isaac of the geology of the Olorgesailie Formation. Sarah Bunney

Sarah Bunney was recently Editor at The International Louis Leakey Memorial Institute for African Prehistory in Nairobi, Kenya.

the experimental techniques used, including directions for the preparation and presentation of samples for analysis, descriptions of discrete and continuous measurements with explanations of calibration and standardisation techniques. This chapter finishes with an account of automated methods of analysis and the use of ion-selective electrodes in biochemistry, biology and medicine.

The final long chapter surveys the applications, as reported in the world's literature until about the end of 1977. It seems to be comprehensive; some 840 references are reviewed in 78 pages. These are dealt with rather in order of the reliability of present-day electrodes, starting with the applications for halogens and cyanide in greatest detail and continuing with sulphur compounds, nitrogen (including enzyme reactions), phosphorous and other nonmetals more briefly. Cation-selective electrodes are treated in the same way, starting with alkali and alkaline earth metals, followed by silver, mercury and so on. The book continues with tabulations for the determination of various inorganic materials and organic compounds and concludes with an Appendix of useful data tables.

This then is a valuable text and one does not need to criticise such honest work on the part of the authors. However, it is hoped that at a later time they mav be encouraged to include the glass $p \mathrm{H}$ electrode, purposely avoided in this volume, as it is still the 'best' ion-selective electrode.

J. A. W. Dalziel

J. A. W. Dalziel is Reader in Analytical Chemistry at Chelsea College, University of London, $U K$. 